\title{
Special issue: recent advances in Cambrian to modern cephalopod research I
}

\author{
Christian Klug $^{1} \cdot$ René Hoffmann $^{2} \cdot$ Dirk Fuchs $^{3} \cdot$ Daniel Marty $^{4}$
}

Received: 30 June 2015/Accepted: 2 July 2015 / Published online: 18 September 2015

(C) Akademie der Naturwissenschaften Schweiz (SCNAT) 2015

\begin{abstract}
In September 2014, the 9th International Symposium Cephalopods-Present and Past was held at the Universitz of Zurich in combination with the 5th International Coleoid Symposium. Here, give a short account of these two events.
\end{abstract}

Keywords Cephalopoda $\cdot$ Coleoidea $\cdot$ Fossil $\cdot$ Recent

\section{Introduction}

From the 04th to 14th September 2014, the 9th International Symposium Cephalopods-Present and Past (ISCPP) was held in combination with the 5th International Coleoid Symposium at the University of Zurich (Lectures on the 07th to 10th September 2014 in KO2-F-180, Universität

Christian Klug

chklug@pim.uzh.ch

René Hoffmann

rene.hoffmann@rub.de

Dirk Fuchs

dfuchs@mail.sci.hokudai.ac.jp

Daniel Marty

martydaniel@hotmail.com

1 Palaeontological Institute and Museum, University of Zurich, Karl Schmid-Strasse 4, 8006 Zurich, Switzerland

2 Institut für Geologie, Mineralogie und Geophysik, Ruhr Universität Bochum, Universitätsstrasse 150, 44801 Bochum, Germany

3 Earth and Planetary System Science, Department of Natural History Sciences, Hokkaido University, Sapporo, Japan

4 Naturhistorisches Museum Basel, Augustinergasse 2, 4001 Basel, Switzerland
Zentrum). This series of ISCPP meetings was launched in the seventies in York. Thereafter, they were held each third to fourth year in various cities including Tübingen, Granada, Vienna, Fayetteville, Sapporo, and Dijon. It is the only occasion, on which cephalopod workers from the entire planet with both paleontological and neontological approaches meet, and in September 2014 in Zurich, it was again an equally friendly and stimulating meeting.

Zurich had already run for the 2010-meeting, which was then carried out in Dijon. When it came to decide, which institution could organise the meeting after Dijon, the Palaeontological Institute and Museum of the University of Zurich was the only candidate. Since the same organisers had agreed to organise the Annual meeting of the Palaeontological Association in 2013, it was decided that the ISCPP can be held in 2014 instead. This led to the seeming "conflict" in the timing of the International Coleoid Symposium, which was quickly resolved by fusing the two series of symposia for the first time. The fusion made sense since many participants of the International Coleoid Symposium also tend to visit the ISCPPs (Figs. 1, 2).

As in the preceding ISCPPs, 4 days of scientific presentations were organised. One of the main foci of this meeting is that both biologists and palaeontologists meet; as always, however, there were more palaeontologists like in the preceding meetings. Although the 2014-meeting the symposium Cephalopods-Present and Past hosted the International Coleoid Symposium, the percentage of researchers working on recent forms was still not very high, but luckily sufficient for some excellent sessions on recent cephalopods, particularly coleoids.

Just as in previous ISCPPs, several fieldtrips were offered around the meeting (Klug and Etter 2014). This time, we organised a first three-day fieldtrip to some 


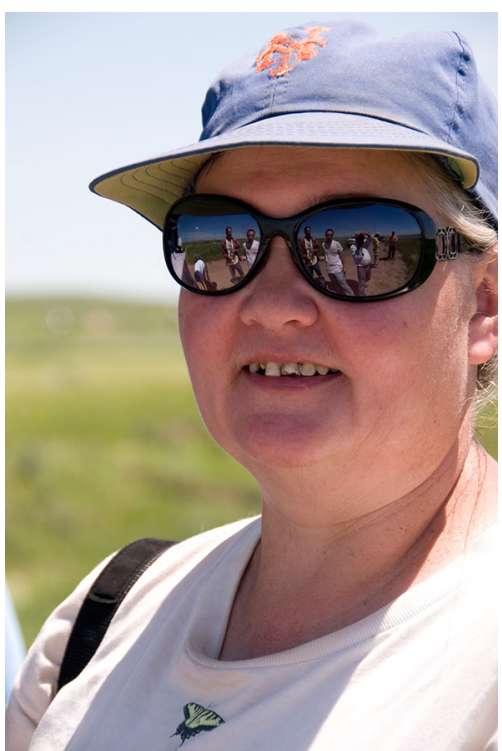

Fig. 1 Susan Klofak (1956-2015). Image courtesy Neil Larson

cephalopod-bearing Fossillagerstätten of southern Germany, a second one-day trip to the Jurassic of the canton Aargau (Switzerland) and a third four-day trip to Mesozoic fossil localities yielding cephalopod fossils in Switzerland and eastern France.

A remarkable number of nearly 30 manuscripts have been submitted for the proceeding volumes of the two meetings (Klug and Fuchs 2014), about a third of which on coleoids, one on nautilids and the rest on ammonoids. Because of the great number of manuscripts, we decided to distribute the contributions over two volumes. Consequently, there will be a second editorial, where we will provide short reports from the fieldtrips. In order to reflect the diversity and disparity of both the cephalopods themselves and the research on this fascinating group, we have decided to distribute manuscripts largely according to their order of acceptance over the two volumes.

\section{Dedication}

In 2014 and 2015, several highly esteemed cephalopod researchers passed away: Fabrizio Cecca (France), David Raup (USA), Reinhart Gygi (Switzerland), Hiromichi Hirano (Japan), Helmut Hölder (Germany), Susan Klofak (USA), Adolf Seilacher (Germany), and Gerd E. G. Westermann (Canada). In the context of our Proceedings, we want to commemorate their important contributions to cephalopod research.

In particular, we want to dedicate this first volume to Susan Klofak, Senior Museum Technician in the Division of Paleontology at the American Museum of Natural
History (AMNH) in New York. For many of the cephalopod research community, the ISCPP was the last time to meet Susan in person. Also, her last paper will be published here. The following text was contributed by Neil Landman, who worked at the AMNH with her for many years:

Susan died on May 15, 2015, while on an AMNH fossil field expedition to Nevada. She arrived at the American Museum of Natural History (New York) in 1984, having earned a Bachelor's degree in geology from Barnard College. She loved palaeontology and pursued a Master's degree at Stony Brook University with Peter Bretzky on Palaeozoic fossils from New York State (her Master's thesis was published in Science: Bretsky and Klofak 1985). She was hired at the Museum to do invertebrate palaeontology preparation, and with her sharp eye and technical skills, she quickly became an invaluable assistant to Neil Landman, Norman Newell, Niles Eldredge, and Melanie Hopkins. Susan especially enjoyed working with the dozens of students, both graduate and undergraduate, who came through the lab over the years, advising them on preparation techniques, helping them curate their fossils, and teaching them to pack and unpack fossils. She participated in dozens of AMNH field collecting expeditions including the Northern Great Plains, Nevada, Missouri, Mississippi, France, Spain, Germany, Switzerland, and Japan, and attended numerous professional meetings to present papers. She developed a real interest in ammonites, and published several co-authored papers on ammonites from South Dakota and New York State. Her two most recent papers (Klofak and Landman 2015; Landman et al. 2015) are published in the ISCPP special issues of the Swiss Journal of Palaeontology. In recognition of her work and dedication, Neil Landman named a species in her honour, Hoploscaphites sargklofak (April 30, 2015). In addition to her love of palaeontology, everyone will remember Susan for her passion for the Mets (even when they lost).

To honour her commitment to cephalopods and also her great personality, we dedicate this first volume of the Proceedings of the ISCPP to her memory!

\section{Lectures}

In total, 84 abstracts for oral presentations and 45 abstracts for posters were accepted. Among the oral presentations, 63 were part of the sessions on cephalopods excluding coleoids, mostly fossil (September 7th to 9th), and 21 dealt with coleoid cephalopods, mostly recent (September 9th to 10th). Three talks were cancelled for various reasons (two of which because of health issues). It is not reasonable to summarise all talks here, so we will briefly give an overview over the key notes only. 


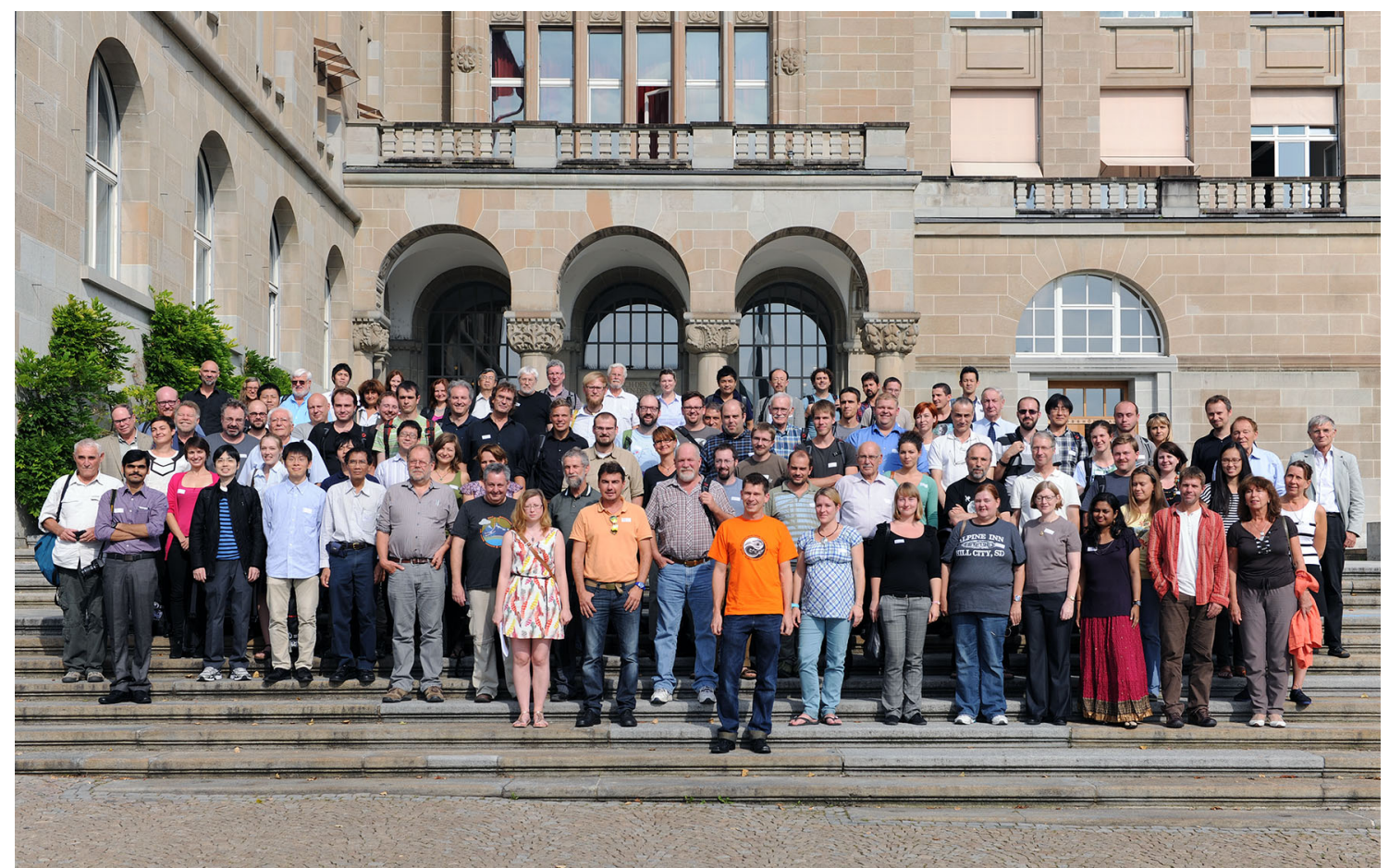

Fig. 2 Group photo of the participants of the 9th International Symposium Cephalopods-Present and Past in combination with the 5th International Symposium Coleoid Cephalopods through Time, taken by Rosi Roth (Zurich) in front of the entrance of the University of Zurich

Björn Kröger (Finnish Museum of Natural History, Helsinki) reported on the initial cephalopod diversification during the Cambrian. Both the initial radiation and the Ordovician radiation were intense and produced a stunning early diversity and disparity. Still on September 7th, Sonny A. Walton (Museum für Naturkunde Berlin) presented his research on the ontogeny of ammonoids. Isabelle Kruta (American Museum of Natural History, New York) talked about the new possibilities of applications of CT-scans for cephalopod-palaeontology. As an example, she presented arm-hook-like structures from ammonite body chambers. Dieter Korn (Museum für Naturkunde Berlin) entitled his presentation "The taxonomic geometry of the Palaeozoic ammonoids". He found that most ammonoid genera contain about five species and searched for possible explanations for this pattern. Hugo Bucher (University of Zürich) explained the major results of his and his workgroup's research on the end-Permian extinction and the Early Triassic rediversification. Evgeny S. Sobolev (Trofimuk Institute of Petroleum Geology and Geophysics SB RAS, Novosibirsk) is one of the leading experts on Triassic nautiloids and showed how they were distributed over the globe. Later, Horacio Parent (Universidad Nacional de Rosario) introduced a new interpretation of the function of ammonite aptychi. On the same afternoon, Larisa A. Doguzhaeva (Swedish Museum of Natural History, Stockholm) spoke about soft-tissue attachment of
Cretaceous ammonites. Neil H. Landman (American Museum of Natural History, New York) ended the session on Cretaceous ammonites with a talk on their extinction, which actually might have occurred slightly after the Cretaceous/Palaeogene boundary. The last ammonite-session began with Benjamin J. Linzmeier's (University of Wisconsin-Madison) talk on the possible habitats as reflected in his fine measurements of stable isotopes in excellently preserved ammonite shells. Peter. D. Ward (University of Adelaide) was supposed to hold a key note on recent pearly Nautilus, but he could not attend the meeting because of serious health issues. A short summary of his results was then presented by Neil Landman for him.

Dirk Fuchs (Hokkaido University, Sapporo) opened the "5th International Symposium Coleoid Cephalopods through Time" with his presentation on the locomotion system of fossil octobrachians and its meaning for both systematics and phylogeny. This day ended with the conference dinner in the restaurant "Weisser Wind". Before the dinner, the members of the scientific committee honoured Neil Landman (New York) and Royal H. Mapes (Ohio) for their life time achievements and important contributions to cephalopod research. Notably, both colleagues had their focus on ammonoids, but both also worked on coleoids including recent species.

The next day was fully dedicated to squid research. Yasuhiro Iba (Hokkaido University, Sapporo) started the 
first session with a talk on the earliest belemnites. $\mathrm{He}$ provided evidence that belemnites originated in the Triassic and pointed at the possibility of an even earlier origin in the Permian. Inger Winkelmann from the University of Copenhagen showed that she found evidence that the specimens of giant squids that have been found worldwide are genetically very similar and probably belong to one species. The last key note was by Henk-Jan Hoving (GEOMAR Helmholtz Centre for Ocean Research Kiel). He presented impressive new footage of various squid documenting highly specialized life cycles of deep-sea cephalopods.

\section{List of participants}

D. Aiba, A. Alifirov, A. Arkhipkin, M. Aubrechtová, M. Balini, J. Bardin, F. Barroso-Barcenilla, R. T. Becker, Y. Bogomolov, L. Bonnaud-Ponticelli, A. Brayard, J. Brezina, H. Bucher, K. Bylund, L. Chang, J. K. Cochran, K. De Baets, A. Di Cencio, L. Doguzhaeva, E. Dunca, R. Dutta, O. Dzyuba, R. Enay, W. Etter, D. Evans, T. Fischer, D. Fuchs, M. Garb, M. Gasalla, L. Glinskikh, S. Goolaerts, M. Hart, K. Histon, R. Hoffmann, J. Hoving, J. Hrbek, Z. Hughes, Y. Iba, C. Ifrim, K. Ikuno, A. Ippolitov, R. Jattiot, J. Jenks, M. Kakabadze, A. King, C. Klein, S. M. Klofak, C. Klug, V. Konovalova, D. Korn, M. Kostak, B. Kröger, I. Kruta, A. Lacchia, N. L. Landman, E. Larina, R. Lemanis, P. Lienert, B. Linzmeier, A. Lukeneder, R. H. Mapes, M. Meier, A. Mironenko, V. Mitta, C. Monnet, A. Morard, H. Mutvei, J. Nabhitabhata, C. Naglik, P. Neige, S. Nikolaeva, H. Parent, J. A. Pérez Valera, A. Pictet, J.-P. Pinard, G. Radtke, M. Reid, M. Reolid, K. Ritterbush, M. Rogov, I. Rouget, A. Roy, G. Schweigert, B. Seuss, O. Smyshlyaeva, E. Sobolev, D. Stephen, H. Summesberger, O. Szives, A. Tajika, A. Takahashi, Y. Takeda, K. Tanabe, S. Tomano, Y. Tsujino, V. Turek, T. Ubukata, J. Vinther, S. von Boletzky, S. Walton, R. Wani, P. D. Ward, D. Ware, R. Weis, I. Winkelmann, M. M. Yacobucci, A. Zacai, Y. Zakharov, and T. Zawadowski.

\section{Summary}

With ca. 110 participants from 26 different countries and all parts of palaeontology and neontology of cephalopods, the 9th International Symposium Cephalopods-Present and Past in combination with the 5th International Symposium Coleoid Cephalopods through Time can be considered a great success. We have received almost exclusively positive feedback and we are convinced that the foundations for numerous new scientific relationships and collaborations have been created.

Acknowledgments We greatly appreciate the generous financial support of the following institutions: Swiss National Science Foundation SNF (project numbers IZ71Z0_152711 and 20CO21_153740), Mathematisch Naturwissenschaftliche Fakultät der Universität Zürich (MNF of UZH), Schweizerische Paläontologische Gesellschaft (SPG/ SPS) with the Scnat, the Palaeontological Association, Subcommission on Triassic Stratigraphy, Nagra, and the city of Zürich. Without this support, these meetings would have been impossible. The following institutions and persons helped organising the meetings: Naturhistorisches Museum Basel (Walter Etter), Naturhistorisches Museum Bern (Ursula Menkveld-Gfeller), Staatliches Museum für Naturkunde Stuttgart (Günter Schweigert), and Werkforum in Dotternhausen (Annette Schmid-Röhl). As far as the organisation is concerned, Heike Götzmann and Andrea Spring (both Zürich) were the greatest help and the meeting would have been impossible without their collaboration. Numerous additional persons supported the preparation of the meetings and the fieldtrips and/or assisted during the symposia: Borhan Bagherpour, Morgane Brosse, Juan David Chorillo, Linda Frey, Manuela Fuchs, Madeleine Geiger, Mischa Haas, Richard Hofmann, Romain Jattiot, Ashley Latimer, Marc Leu, Maximiliano Meier, Carole Meier/Naglik, Carlo Romano, Madlen Stange, Amane Tajika, Kristof Veitschegger, Heinrich Walter, David Ware (all Zürich), and Antoine Pictet (Lausanne). Their help is greatly acknowledged. Finally, we thank the KSPA (Commission of the Swiss Palaeontological Memoirs) for having facilitated the publication of this special issue in the Swiss Journal of Palaeontology.

\section{References}

Bretsky, Peter W., \& Klofak, S. M. (1985). Margin to craton expansion of Late Ordovician benthic marine invertebrates. Science, 227, 1469-1471. doi:10.1126/science.227.4693.1469.

Klofak, S.M., \& Landman, N.H. (2015). Ontogeny and morphology of the retrochoanitic septal necks of Agoniatites vanuxemi from the Middle Devonian Cherry Valley Limestone. Swiss Journal of Palaeontology. doi:10.1007/s13358-015-0092-z.

Klug, C., \& Etter, W. (2014) (Eds.). Field guide to the excursions "Fossillagerstätten of the southern German Jurassic" and "Mesozoic ammonoid localities of Switzerland and eastern France". 9th International Symposium Cephalopods-Present and Past in combination with the 5th International Symposium Coleoid Cephalopods through Time. 1-50. Zürich, Paläontologisches Institut und Museum, Universität Zürich.

Klug, C., \& Fuchs, D. (2014) (Eds.). Abstracts and program. 9th International Symposium Cephalopods-Present and Past in combination with the 5th International Symposium Coleoid Cephalopods through Time. 1-150. Zürich, Paläontologisches Institut und Museum, Universität Zürich.

Landman, N.H., Grier, J.C., Grier, J.W., Cochran, J.K., Klofak, S.M. (2015). 3-D Orientation and distribution of ammonites in a concretion from the Upper Cretaceous Pierre Shale of Montana. Swiss Journal of Palaeontology, 134, 15. 